\title{
Therapeutic Community (TC) pada Residen Penyalah Guna Narkoba di Panti Social Marsudiputra Dharmapala Inderalaya Sumatera Selatan
}

\author{
Syarifuddin Gani ${ }^{1^{*}}$ \\ ${ }^{1}$ BK FKIP Universitas Sriwijaya
}

\begin{abstract}
Terapi dan rehalibitasi korban penyalahgunaan narkoba, merupakan sistem pelayanan terpadu dengan menggunakan Therapeutic Community (TC) merupakan treatment yang menggunakan pendekatan psikososial, yaitu bersama-sama dengan mantan pengguna narkoba lainnya mereka hidup dalam satu lingkungan dan saling membantu untuk mencapai kesembuhan. Dalam rangka memberikan layanan rehalibitasi di Panti Sosial Marsudi Putra Dharmapala Indralaya. Proses perubahan yang diharapkan dari Therapeutic Community (TC) adalah perubahan tingkah laku perkembangan emosi, perkembangan intelektual, spiritual dan keterampilan kerja serta memberikan perhatian, perlindungan, dan mendukung perkembangan secara fisik, mental, dan spiritual yang seimbang, dengan penuh cinta kasih dan rasa saling menghargai terhadap setiap individu dan komunitas secara keseluruhan, sehingga terciptanya keharmonisan didalam lingkungan tersebut. Adapun yang menjadi tujuan dari penelitian ini adalah untuk mendapat gambaran mengenai hasil penerapan Therapeutic Community (TC) pada residen penyalahguna narkoba terjadinya perubahan tingkah laku pada ketiga residen setelah mengikuti proses rehabilitasi karena penyalah gunaan narkoba disebabkan oleh interaksi antara factor yang terkait dengan individu, factor lingkungan dan factor tersedianya zat (narkoba).
\end{abstract}

Keyword: Therapeutic Community, korban, rehabilitasi

Copyright (C 2013 IICE - Multikarya Kons - All Rights Reserved Indonesian Institute for Counseling and Education (IICE) Multikarya Kons

\section{PENDAHULUAN}

Penyalahgunaan narkoba kini merupakan salah satu masalah serius, dirasakan tidak saja pada tingkat lokal, nasional melainkan juga tingkat internasional. Permasalahan penyalahgunaan narkoba dan peredaran gelap narkoba akhirakhir ini menunjukkan peningkatan yang mengkhawatirkan dan berdampak pada hilangnya suatu

\footnotetext{
Telp dan/atau Alamat Email Koresponden : 'Email: syarifuddin@fkip.unsri.ac.id
} 
Jurnal Konseling dan Pendidikan

http://jurnal.konselingindonesia.com

Vol. 1 No. 1, Februari 2013. hlm. 54 - 57

generasi muda bangsa. Untuk itu perlu penanganan korban penyalahgunaan narkoba yang professional serta berbasis masayarakat melalui system panti terapi dan rehabilitasi.

Metode Therapeutic Community (TC) merupakan treatment yang menggunakan pendekatan psikososial. Bersama-sama dengan mantan pencandu narkoba lainnya mereka hidup dalam suatu lingkungan dan saling membantu untuk mencapai kesembuhan. Aktivitas-aktivitas yang ada dalam Therapeutic Community (TC) dirancang untuk membantu mantan pencandu narkoba untuk menguji belief, konsep diri dan pola prilaku yang salah serta mengadopsi cara baru yang lebih harmonis dan konstruktif dalam berinteraksi dengan orang lain .Peran konselor selain membimbing residen adalah sebagai contoh bagi para resident lain agar melakukan perubahan tingkah laku yang tidak diterima oleh resident kearah tingkah laku yang positif.

Dalam rangka memberikan layanan rehabilitasi bagi para eks penyalahguna narkoba, panti sosial Marsudi Putra Dharmapala Indralaya menerapkan Therapeutic Community (TC). adalah suatu tempat yang memungkinkan bagi penyalahguna narkoba untuk melakukan perubahan tingkah laku yang tidak diterima oleh masyarakat kearah tingkah laku yang positif. Hal ini dimungkinkan karena lingkungan TC memberikan situasi yang mendorong residen untuk mengungkapkan permasalahan pribadinya dan lingkungan TC melakukan intervensi untuk mengatasinya. Penelitian ini akan mengunggkapkan bagaimana Bagaimana Penerapan Therapeutic Community pada residen penyalahguna narkob secara khusus bertujuan untuk mendapatkan gambaran mengenai hasil penerapan Therapeutic Community pada residen penyalahgunaan narkoba. Diharapkan dengan penelitian ini secara akademis dapat menjadi bahan referensi bagi pengembangan ilmu kesejahteraan social secara nyata dalam mengembangkan metode-metode pelayanan social bagi korban narkoba dan bagi konselor disekolah secara nyata mampu melaksanakan layanan baik secara preventif, curative maupun preservative.

\section{METODOLOGI}

Penelitian ini merupakan suatu penelitian evaluasi yang mencari jawaban tentang pencapaian tujuan yang digariskan sebelumnya . Evaluasi disini mencakup formatif (melihat dan meneliti pelaksanaan program), Sumatif (dilsaksanakan pada akhir program untuk mengukur pencapaian tujuan) dengan melibatkan subjek dan menerapkan penerapan Therapeutic Community dan residen penyalahgunaan narkoba di Panti Sosial Marsudi Putra Dharmapala Indralaya Sumatera Selatan.

\section{HASIL DAN PEMBAHASAN}

Setelah dilakukan penelitian dapat diketahui bahwa keberhasilan penerapan Therapeutic Community Terhadap risiden Penyalah gunaan narkoba berdasarkan empat kategori perubahan yaitu :

\section{Perubahan tingkah laku}

Ciri khas yang dimiliki oleh residen yaitu tidak adanya kemampuan untuk menyesuaikan diri dengan norma yang positif yang ada dilingkungan panti, cendrung memperlakukan norma yang ditegakan pada kelompoknya sendiri. Sehingga bagi mereka yang melakukan penyimpangan penyimpangan terhadap norma yang berlaku dirasakan sebagai suatu yang biasa. Perilaku negatif tersebut diupayakan untuk dapat berubah melalui berbagai metode serta penegakan norma yang positif yang telah disepakati bersama.

\section{Perkembangan emosi}

Aspek stabilitas emosi sangat diperhatikan dalam pelayanan Therapeutic Community karena ketiga residen memiliki emosi yang labil, mudah tersinggung, pemalas, mau menang sendiri, murung, minder, depresi. Kondisi tersebut juga mengakibatkan sulitnya residen menyesuaikan diri dalam kehidupan yang wajar dimasyarakat. Therapeutic Community memberikan pelayanan dan menciptakan kondisi yang dapat mengarahkan residen untuk dapat mengontrol stabilitas emosi. Hal ini dapat dilakukan melalui kegiatan konseling individual, bimbingan kelompok, konseling keluarga, encounter dan psikodrama.

\section{Perkembangan Intelektual/Spiritual}

Aspek lain yang mempunyai perhatian adalah perkembangan intelektual . Beberapa residen kemungkinan memiliki potensi intelegensi yang cukup baik. Namun kadang-kadang tidak dapat berkembang secara optimal 
karena adanya permasalahan yang dihadapi Sebagian dari mereka hanya pendidikan tingkat menengah. Namun meskipun demikian tetap diupayakan pengembangan secara intelektual dengan cara melatih krativitas, memberikan materi-materi yang berkaitan dengan pengembangan dirinya dan pendidikan formal.

\section{Ketrampilan Kerja}

Dalam lingkungan Therapeutic Community pengertian ketrampilan tidak semata-mata diarahkan pada kegiatan ketrampilan yang produktif, tetapi juga dimanfaatkan untuk menumbuhkan rasa percaya diri, menanamkan tanggung jawab, pemahaman bahwa setiap pekerjaan itu bermanfaat. Selanjutnya mereka diberikan pelayanan ketrampilan kerja yang bersifar produktif.

Dalam setiap kegiatan ataupun program yang diterapkan dalam Therapeutic Community (TC), selalu dikaitkan dengan tiga aspek yaitu: thinking, feeling, acting. Jadi dalam kehidupan residen diupayakan adanya keseimbangan perkembangan tiga hal tersebut.

Empat (4) kategori perubahan yang diharapkan dapat terwujud dalam kegiatan Therapeutic Community yaitu:

1.Perubahan Tingkah Laku

Ciri khas yang dimiliki oleh resident yaitu tidak adanya kemampuan untuk menyesuaikan diri dengan norma yang ada dilingkungannya yaitu keluarga, sekolah, maupun masyarakat. Mereka cenderung memperlakukan norma yang ditegakkan pada kelompoknya sendiri. Sehingga bagi mereka melakukan penyimpangan-penyimpangan terhadap norma yang berlaku dirasakan sebagai sesuatu yang biasa. Perilaku negatif tersebut dupayakan untuk dapat berubah melalui berbagai metode serta penegakan norma positif yang telah disepakati bersama

\section{Perkembangan Emosi}

Aspek stabilitas emosi sangat diperhatikan dalam pelayanan TC. Karena umum-nya residen memiliki emosi labil, mudah tersinggung, pemalas, mau menang sendiri, murung, minder, depresi. Kondisi tersebut juga mengakibatkan sulitnya residen menyesuaikan diri dalam kehidupan yang wajar di masyarakat

Therapeutic Community memberikan pelayanan dan menciptakan kondisi yang dapat mengarahkan residen untuk dapat mengontrol stabilitas emosi. Hal ini dapat dilakukan melalui kegiatan konseling individual, bimbingan kelompok, konseling keluarga, encounter dan psikhodrama.

\section{Perkembangan Intelektual/Spiritual}

Aspek lain yang menjadi perhatian adalah perkembangan intelektual. Beberapa residen kemungkinan memiliki potensi intelegensi yang cukup baik. Namun kadang-kadang tidak dapat berkembang secara optimalkarena adanya permasalahan yang di-hadapinya. Sebagian dari mereka mungkin hanya berpendidikan sangat minm. Namun meskipun demikian tetap di upayakan pengembangan secara intelaktual dengan cara melatih kreatifitas, memberikan materi-materi yang berkaitan dengan pembangunan pribadinya, pendidikan formal.

\section{Keterampilan Kerja}

Dalam lingkungan TC pengertian keterampilan tidak semata-mata diarahkan pada kegiatan keterampilan yang produktif, tetapi juga dimanfaatkan untuk menumbuh-kan rasa percaya diri, menanamkan tanggung jawab, pemahaman bahwa setiap pekerja-an itu bermanfaat. Selanjutnya mereka diberikan pelayanan keterampilan kerja yang bersifat produktif.

\section{PENUTUP}


Jurnal Konseling dan Pendidikan

\section{Kesimpulan}

1. Tujuan penerapan Therapeutic Community adalah terjadinya perubahan tingkah laku,perkembangan emosi, perkembangan intelektual, spiritual dan ketrampilan kerja .Hasil analisis yang dilakukan didapat adanya perubahan pada ketiga residen setelah mengikuti proses rehabilitasi di Panti. Penerapan Therapeutic Community sesuai dengan tujuan dan harapan sehingga dapat disimpulkan berhasil.

2. Therapeutic Community menggunakan beberapa layanan konseling seperti Bimbingan kelompok, konseling individual dan konseling kelompok dalam melatih mengontrol stabilitas emosi, meningkatkan rasa persaudaraan, melatih kreativitas, menghilangkan rasa stress belajar memahami permasalahan, mengekpresikan rasa ketidak puasan, mencari pemecahan suatu masalah

\section{Saran}

Saran diperlukan penelitian Therapeutic Community lanjutan yang relevansinya dalam pemberian layanan Bimbingan konseling

\section{DAFTAR PUSTAKA}

Arikunto, Suharsimi. 2006. Prosedur Penelitian. Jakarta: Renika Cipta

Arikunto, Suharsimi. 2006. Prosedur Penelitian Suatu Pendekatan Praktik. Jakarta: Renika Cipta

Badan narkotika bekerjasama dengan departemen sosial republic Indonesia. 2003. Metode therapeutic. Jakarta.

BNN RI. 2007. Mencegah lebih baik dari pada mengobati. Jakarta: BNN RI.

BNN RI. 2008. Petunjuk teknis advokai bidang pencegahan penyalahgunaan narkoba.. Jakarta: BNN RI.

BNN RI. 2007. Advokasi pencegahan penyalahgunaan narkoba. Jakarta: BNN RI.

Undang-undang no. 35 tahun 2009 tentang Narkotika.

Surat edaran mahkamah agung republik Indonesia nomor 07 tahun 2009 tentang menempatkan pemakai narkoba ke dalam panti terapi dan rehabilitasi.

Departemen Sosial RI. 2002. Model Pelayanan dan Rehabilitasi Terpadu Bagi Korba Penyalahguna Napza. Jakarta: Departemen Sosial RI

Hawari, dadang. 2004. Terapi dan Rehabilitasi Pasein Napza. Jakarta: universitas Indonesia.

Sugiono. 2002. Metode Penelitian Pendidikan. Bandung: alfabeta

Gunarasa, singgih D. 1983. Psikologi Perkembangan Anak dan Remaja. Jakarta: PT BPK Gunung Mulia.

Hikmat, mahi M. 2007.Awas Narkoba Para Remaja Waspadalah. Bandung: PT. Grafitri.

Hidayat. 1986.Efektifitas Bimbingan Dan Konseling Di Sekolah Menegah. Bandung: CV. Ilmu.

Legitasari, rini. 2009. Penerapan metode Therapeutic community dalam pembinaan narapidana pemakai narkoba. Bandar Lampung: Fakultas Hukum Universitas Lampung.

http://www.bnn.go.id/portabaru/portal/konten.php?nama=jenisNarkoba\&op=detail_jenis_narkoba\&mn=2smn=a7i djenis $=1 \&$ idmacam $=2$

http://wwwilmumetodepenelitian.blogspot.com/2009/11/penelitian-evaluasi.html 